\title{
Impact of globalization on the direct participation of citizens in local self-government in the Republic of Bulgaria
}

\author{
Margarita Cheshmedzhieva ${ }^{1}$, Vesela Mircheva $^{1}$, Galina Pisarska ${ }^{2,}$, , and Elena Haydushka ${ }^{1}$ \\ ${ }^{1}$ South-West University "Neofit Rilski”, Faculty of Law and History, Department of Public Law, sq. \\ "Georgi Izmirliev - Makedoncheto" 1, 2700 Blagoevgrad, Bulgaria \\ ${ }^{2}$ South-West University "Neofit Rilski”, Faculty of Law and History, Department of International Law \\ and International Relations, sq. "Georgi Izmirliev - Makedoncheto" 1, 2700 Blagoevgrad, Bulgaria
}

\begin{abstract}
.
Research background: The direct participation of citizens in political decision-making in the state is one of the ways to implement the public relations between the political state represented by the authorities of local self-government and administration. In addition to that, the civil society on behalf of the local inhabitants of the municipalities is also part of this process.

Purpose of the article: This report aims to examine which forms of direct democracy are most often applied in the system of local self-government and what is the result of them in view of the economic independence of municipalities. The comparative study covers the periods before and after the signing of the European Charter of Local Self-Government in 1995 by the Republic of Bulgaria, as well as the periods before and after the accession of our country to the EU in 2007. These two events play a key role in the impact of globalization processes on the direct participation of citizens in local political decision making.

Methods: The methodological tools, used in the research, include the comparative analysis and the comparative-legal method.

Findings \& Value added: The contribution of the research is expressed in tracking the trend in the application of various forms of direct participation of citizens in local government in the Republic of Bulgaria, in outlining the main shortcomings of legal regulations and factors, favoring or hindering the implementation of these forms, and in formulating proposals de lege ferenda to improve existing legislation.
\end{abstract}

Keywords: direct participation of citizens in local self-government; European Charter of Local Self-Government; local referendum; local civil initiative; general assembly of the population

JEL Classification: $K 10 ; K 38$

*Corresponding author: galina_pisarska@abv.bg 


\section{Introduction}

The Republic of Bulgaria shall be an unitary State with local self-government and no autonomous territorial formations shall be allowed to exist therein (Art. 2, para. 1 of the Constitution). The local self-government is a means of decentralizing state power. In other words, it provides the right and opportunity for the local population (within the respective administrative-territorial unit) to solve local problems independently and on their own responsibility and to meet local needs. There are two ways to achieve this - either through local self-government's bodies such as municipal councils, or through forms of direct democracy in local self-government. Globalization is a phenomenon that affects the development of public relations not only at the supranational, but also at the national level. In this regard, in 1995 the Republic of Bulgaria signed the European Charter of Local SelfGovernment (ECLSG), adopted by the Council of Europe in 1985, committing itself to implementing in domestic law the principles of local self-government, enshrined in the Charter. After Bulgaria's accession to the European Union in 2007, a new legal framework for the forms of direct democracy was adopted. Differentiated integration is generally understood as a tool to accommodate the increasing heterogeneity of preferences in an enlarging and deepening European Union [1]. These two events inevitably include our country in the so-called "globalization process", raising "the larger question of democratic rule in an era of increased globalization" [2].

\section{Methods}

The methodological tools, used in the research, include the comparative analysis and the comparative-legal method. The comparative analysis is used to examine the data on the implementation of various forms of direct democracy in local self-government. The comparative-legal method is used to analyse the dynamics of the implementation of forms of direct democracy in local government in the Republic of Bulgaria and the Switzerland as one of the leading countries in the world in which direct democracy is widely applied. It should be borne in mind that both states have signed the ECLSG.

\section{Results and discussions}

\subsection{Forms of direct democracy in local self-government in the Republic of Bulgaria}

The first law in the field of direct democracy, adopted after the signing of the ECHR, is the Law on Public Consultation (LPC), adopted in 1996 and in force until 2009. It envisages three forms of direct citizen participation in municipal governance - local referendum, General Assembly of the Population and subscription. The theory of constitutional law however maintains that the subscription is not a real form of direct democracy [3]. After the accession of the Republic of Bulgaria to the European Union in 2007, a new Direct Citizen Participation in State and Local Government Act (DCPSLGA) was adopted in 2009, which repealed the current LPC. At the local level, it also regulates three forms of direct participation - a local referendum, a local civil initiative and a General Assembly of the Population.

The referendums, gives people the power to control the public will as a distinctive feature of modern democracy“ [4,] without being used for populist purposes [5]. Through the local referendum (art. 26-43 of DCPSLGA) issues of local importance are directly resolved, which have been vested, by law, within the competence of the local government authorities or 
bodies of the district/sub-municipal unit. Three categories of issues are excluded from its scope - the issues related to the municipal budget; issues pertaining to the amount of local taxes and charges; issues pertaining to the rules of internal procedure and operation of the Municipal Council. By its legal nature, the local referendum, regulated in the Bulgarian legislation, is definitive or decisive. This means that the decision, adopted by local referendum, has immediate legal consequences and is not subject to subsequent approval by the Municipal Council. The same is obliged to adopt a relevant legal act, when this is necessary for its implementation (Art. 26, para. 4 of the DCPSLGA).

The subjects that can initiate the holding of a local referendum are exhaustively indicated in the text of art. 27, para. 1 of DCPSLGA. Namely - at least one fifth of the municipal councillors, but not less than three municipal councillors; the mayor of the municipality, respectively the mayor of the mayor's office or the region; an initiative committee with the signatures of not less than one twentieth of the citizens with voting rights who have a permanent address on the territory of the respective municipality, district or mayor's office at the time of entering the proposal in the public register of local referendum proposals. When the initiative committee presents a subscription, containing the signatures of not less than one tenth of the citizens with voting rights in the respective municipality, district or mayoralty, the Municipal Council is obliged to adopt a decision for holding a local referendum. If the subscription is not submitted to the Municipal Council within three months from the notification, the procedure for submitting a proposal for a referendum shall be terminated by the Chairman of the Municipal Council. A new petition with a proposal for a referendum on the same issue may be initiated not earlier than 6 months from the termination of the procedure or from one year from the decision of the Municipal Council, rejecting the proposal.

The proposal is addressed to the chairman of the Municipal Council, who within three days of its receipt is obliged to notify the municipal councillors and the mayor of the municipality, appoints a leading committee to discuss it and schedule a meeting of the Municipal Council within one month of its receipt. The proposal for a local referendum shall include one or more questions to which voters shall answer "yes" or "no". The questions are written in common Bulgarian, short, precise and clear. The standing committees and the mayor are obliged to discuss the proposal and present their opinions not later than three days before the meeting of the Municipal Council. They present to the chairman of the Municipal Council a draft decision. This draft approves the proposal to hold a referendum with the question or questions, which will be put to the vote, or rejects the proposal on the grounds. If the Municipal Council finds that the issue is illegal, it shall refuse to hold a local referendum with a reasoned decision.

In its decision to hold a local referendum, the Municipal Council approves the costs of organizing and financing from the municipal budget, as for violations of the budget legislation it is envisaged a political, administrative and criminal responsibility [6]. And the organizational and technical preparation itself is carried out by the mayor and the municipal administration. The proposal, subject of the referendum, shall be considered accepted if the necessary quorum and majority are present under the provisions of Art. 41, para. 1 and 2 of the DCPSLGA. Namely, not less than $40 \%$ of the citizens with voting rights in the respective municipality should have participated in the referendum and more than half of the voters who participated in it should have answered in the affirmative. When the referendum is held simultaneously with general elections for municipal councilors and mayors, the proposal, subject to the referendum, is accepted if more than half of the actual votes cast in the respective municipality in the elections for municipal councilors have answered in the affirmative. If the proposal, subject to the referendum, is not accepted, a local referendum on the same issue may be initiated not earlier than one year from the date of its production. The legality of the results of the local referendum may be challenged by the persons, authorized 
to initiate it, or by the respective regional governor before the respective administrative court, and his decision may be appealed to the Supreme Administrative Court. The decision, adopted through a local referendum, is announced by the chairman of the municipal council on the official website of the municipality, in a regional newspaper and in a regional electronic media. It enters into force immediately after its announcement, and its implementation is organized by the mayor of the municipality, region or town hall.

The local civil initiative is another form of direct participation of the citizens in the local self-government (art. 46-53 of DCPSLGA). Its legal essence is expressed in the submission of proposals by citizens to the Municipal Council, the mayor of the municipality, the region or the mayor's office, or to regional executive bodies for resolving issues of local importance. It is carried out by subscription, organized by an initiative committee on the territory of the respective municipality, region, town hall or settlement.

A decision to organize a local citizens' initiative shall be taken at a meeting of not less than 50 citizens with voting rights and with a permanent or current address on the territory of the respective municipality, region, town hall or settlement. An initiative committee is also elected at this meeting, which will conduct the subscription within two months from the meeting and submit the proposal to the competent authority. It is also his obligation to organize an information campaign and public discussions in connection with the proposal on which the subscription is conducted. The costs related to the organization of the subscription are financed by citizens and legal entities as a result of the successful earning management [7], which in turn reduces the corrupt influence on business development [8].

The municipal council, the mayor or the executive bodies, to which the local citizens' initiative is addressed, are obliged to consider the made proposals and within one month from the delivery of the subscription to announce their decision and the taken measures on the website of the municipality and in a regional newspaper. They are also obliged to inform the initiative committee in a writing form about their decision and about the measures for its implementation.

A General Assembly of the Population/General Populace Meeting (art. 54-64 of the DCPSLGA) is held to resolve issues of local importance, which, if appropriate, are provided in the competence of the respective Municipal Council or mayor of a municipality. They are obliged to issue the relevant legal acts for taking the necessary actions within one month from the adoption of the decision of the General Assembly of the Population in the municipality, region or mayor's office, unless it has determined a longer period. The Municipal Council shall take the necessary actions within one month from the adoption of the decision of the General Assembly of Population in the settlement or residential areas.

A General Assembly of the Population shall be held in municipalities, districts, submunicipal units, towns/cities/villages and residential areas with a population of up to 10,000 citizens. It consists of all citizens with voting rights on the territory of the municipality, district, sub-municipal unit, town/city/village or residential area, who have a permanent or current address in the respective municipality, district or town hall before the date set for the meeting. It is convened by the mayor of the municipality, district or sub-municipal unit on his initiative; by decision of the Municipal Council; at the request of at least one fiftieth, but not less than 20 citizens with voting rights with a permanent or current address on the territory of municipality, district, sub-municipal unit, town/city/village or residential area at the time of formulating the request. In this case, the initiative with a subscription for convening a General Assembly of the Population is organized by an initiative committee of citizens. He submits the subscription to the mayor, who is obliged to convene a General Assembly of the Population within the term specified therein. When the mayor does not convene it in time, the tacit refusal can be appealed to the relevant administrative court. The expenses for the organization of the General Assembly of the Population are covered by the municipal budget. 
The General Assembly of the Population is considered regular if it is attended by at least a quarter of the citizens with voting rights in the municipality, district, sub-municipal unit, town/city/village and residential area. In settlements with up to 150 inhabitants for holding a General Assembly of the Population it is necessary to be present at least one third of the citizens with voting rights in the respective settlement. When the specified number of citizens did not appear at the appointed time, the meeting is postponed by one hour, after which it is held with those who are present. However, their number may not be less than one tenth of all citizens with voting rights. The General Assembly of the Population is held by a commission, whose members are elected by a majority of more than half of the citizens present with voting rights. The decision of the General Assembly is adopted by a majority of more than half of those present and is announced by the chairman of the commission immediately. It is announced by the mayor of the municipality, who issues an order with the specific measures for its implementation or submits a proposal to the Municipal Council for preparation and adoption of a relevant decision, regulation or ordinance. The legality of the General Assembly, as well as of its decisions may be appealed to the respective administrative court, whose decision is final.

\subsection{Forms of direct democracy in Switzerland at a cantonal level}

Switzerland is ,an exceptionally heterogeneous polity“ [9]. The widespread use of various forms of citizen involvement in the legislative process is the basis for defining Switzerland as a classic country of direct democracy in constitutional doctrine. It is also given as a typical example of consociational (negotiation, consensus) democracy, in which there is both joint exercise of power through the mechanisms of party democracy and of the separation of powers in a vertical perspective in view of the federalism [10].

The forms of direct democracy are highly dependent on the environment in which they exist and on the way in which they are practiced by the legal subjects [11]. They fulfill their purpose thanks to the democratic values and principles which the Swiss political system is based on, as well as to the broad civil and political rights, granted to the Swiss, the initiative and activity of civil society, the created conditions for combination the different specific interests and the achievement of national consent through consultation, dialogue and compromises [12].

Mechanisms for civic participation in public administration in Switzerland have been actively practiced for more than 150 years. These instruments of direct democracy are used by Swiss citizens not only at the national (federal) but also at the regional (cantonal) and local (communal) level. By their nature, purposes and manner of implementation, they are practically unchanged compared to the period when they were introduced. Due to the fact that each canton independently chooses the forms of participation, there are over 150 legal frameworks for direct democracy at different levels. In view of the normative hierarchy, their legal regulation can be considered at four levels: federal constitution, cantonal constitutions, federal laws and by-laws. The federal constitution contains the principles in this matter. At the regional level, in view of the autonomy of the individual cantons, these principles are further developed and concretized by the cantonal constitutions. Important provisions on the procedure for holding referendums, citizens' initiatives and petitions, as well as on the interaction of state bodies with citizens' initiative committees are contained in the Federal Law on Political Rights of 17 December 1976 and the Federal Law on the Federal Assembly of 13 December 2002. Procedural and technical issues are further developed in the Decree on Political Rights of 24 December 1978.

Swiss legislation regulates the referendum, the citizens' initiative, the right to petition and the right to provoke a speedy entry into force of law as forms of citizen participation in political decision-making. 
The referendum is considered the cornerstone of direct democracy, which allows citizens to have a direct voice of important political issues and engage in public policy issues [13]. It is a universal form for involving citizens in the legislative process, as well as for legitimizing the political decisions taken by state bodies, which should be dressed in a normative form. In Switzerland, this institution of direct democracy is not an incidental phenomenon, but a common fact of political life, which is repeated every three to six months and concerns many issues [14]. Moreover, referendums provide an environment for observing political elections [15]. In theory, they are also seen as a means to overcome the issues of traditional conflicts between political parties [16] and as a way of legitimizing a political decision that could be a source of ongoing conflict [17]. The referendums are a preferred form because they enable citizens to shape the formation of laws more quickly than legislative procedures that mediate their legal preferences and policy outcomes [18]. Indeed, referendums transfer decisionmaking power to the people [19], although their representativeness is called into question [20].

Different types of referendums are regulated, which can be divided into several groups. In view of the territorial scope, there are a nationwide (federal) referendum and a cantonal referendum. In view of whether the holding of a referendum is a prerequisite for the validity of the legal question, put to the consultation, or is simply an opportunity, a distinction is made between mandatory referendums and optional referendums. Depending on the scope, a distinction is made between partial referendums, which relate only to a part of a bill, another act or proposal, and variant referendums, which offer for approval several possible variants of a proposal.

The mandatory referendum is provided in Art. 140 of the Constitution of Switzerland, in Art. 58 of the Federal Law on Political Rights, as well as in some cantonal legislation. There are two types of mandatory referendum with regard to the subjects that must vote through it on an issue, namely: a referendum that consults both the people and the self-governing communities, and a referendum that consults only the people. The first type of mandatory referendum is held on a full or partial revision of the federal constitution, on joining collective security organizations (e.g. NATO) or supranational communities (e.g. the European Union), and on federal laws that have been declared urgent and whose duration exceeds one year. The second type of mandatory referendums is held only on amendments to the Federal Constitution. According to the provision of Art. 58 of the Federal Law on Political Rights, the specific issues, subject to a mandatory referendum, as well as the draft legislative amendments are promulgated after their adoption by the Federal Assembly before being submitted for approval by referendum. The referendum is conducted by the Federal Council (in the case of referendums throughout the country) or by the relevant cantonal executive bodies (in the case of referendums of cantonal significance).

An optional referendum shall be held if it is requested by 50,000 eligible voters or by eight cantons within 100 days of the official promulgation of a law or other act, subject to an optional referendum. The subject of an optional referendum may be the federal laws; laws that have entered into force expeditiously and have a duration of more than one year; federal decisions, insofar as this is provided by the Federal Constitution or by law; international agreements that are indefinite and cannot be terminated; envisage joining an international organization; contain important normative provisions which, if they were domestic law, would be within the competence of the legislature or for the implementation of which a law is necessary to be adopted in the domestic law.

The partial referendum, the variant referendum and the right to provoke the accelerated entry into force of a law are enshrined in the Constitution of the canton of Schaffhausen. According to Art. 35 of the Schaffhausen Constitution, the Cantonal Council may subject to consultation with the people separate parts of a normative act separately from or together with it. Therefore, a subject of a partial referendum can be problems that need to be resolved 
independently, as well as issues that represent a special emphasis in a normative act and therefore need additional and independent legitimation. The variant referendum gives the opportunity to be voted by the people one or more variants of drafts for a given normative act. This referendum provides the choice of the final concept and formulation again to the people, as the draft that received the most votes is considered approved.

Due to the many types of referendums, regulated by Swiss law, as well as the number and variety of legal acts in which they are regulated, the procedure for holding a referendum is extremely detailed. However, for the above reasons, there are many different procedures. Each canton is responsible for conducting the voting within its territory and has its own provisions, which sometimes differ considerably. Therefore, in the present study it is difficult to consider all the specifics of the procedure, especially since many of them are of a legal and technical nature.

At the local level, six of the cantons provide for the possibility for citizens to recall local government representatives. A local referendum on recall may be scheduled at the request of the local population. The required number of signatures varies in the different cantons between $2 \%$ and $13 \%$ of eligible voters.

Some cantons offer citizens with electoral rights the opportunity to launch a popular legislative initiative (civil initiative). It allows them to request a new cantonal constitution or an amendment to the existing one, as well as the adoption, amendment or repeal of laws or regulations at the cantonal or municipal level. In view of the degree of formulation and concretization, the initiative can be a general or formulated initiative.

The right to petition is a fundamental constitutional right of Swiss citizens. It is provided both in the Federal Constitution (Art. 33) and in the constitutions of the individual cantons. In any case, the initiators of the petition must be informed of the outcome of its consideration. Some cantonal legislation (for example, Art. 20 of the Bern Constitution) provides for a period within which the public authority or local authority, to which the petition is addressed, must rule on it. However, this deadline is instructive. The right to petition can be exercised both independently and in addition to other means of direct citizen participation in legislative process.

The right to provoke the accelerated entry into force of the law is provided in Art. 35 of the Constitution of the canton of Schaffhausen. It is applied in three hypotheses. First, on laws that do not require a reprieve. These laws may enter into force immediately if two-thirds of the members of the Cantonal Council present vote in favor. Second, if a normative act envisages as a condition for accelerated entry into force of the law the holding of a referendum. And third, if a referendum is requested, but it is not held within one year of the law's entry into force, then that law loses force, and when, as a result of the referendum, the law is rejected.

\subsection{A comparison between the applied forms of direct democracy in the Republic of Bulgaria in the system of local self-government and in the Switzerland at the cantonal level for the period 2009-2014}

In Bulgaria for the period of 2009-2014 a total of 22 local referendums were held, almost all of which were initiated with the subscription of the citizens. The subject of these initiatives is mainly the implementation of administrative-territorial changes and environmental issues. The graph in Figure 1 clearly shows that citizens' interest in direct democracy is growing, which is evidence of their greater commitment to public affairs at the local level. In the Republic of Bulgaria there is no unified public register for local referendums, civic initiatives and general assemblies of the population. Municipalities are obliged under the DCPSLGA to create public registers in which to enter only the proposals for a local referendum, but most of them have not fulfilled this obligation. The lack of summarized information on the direct 
participation of citizens at the local level deprives the public of the opportunity to assess the state of this important form of local self-government. This, in turn, does not allow the necessary actions to be taken to solve the problems in the development of local forms of direct democracy.

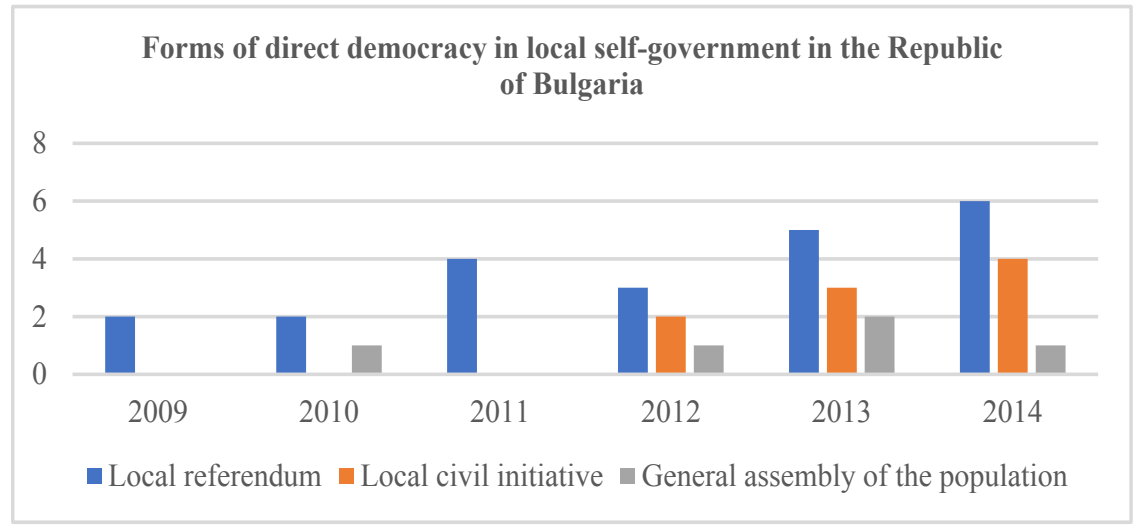

Fig. 1. Forms of direct democracy in local self-government in the Republic of Bulgaria for the period of $2009-2014$

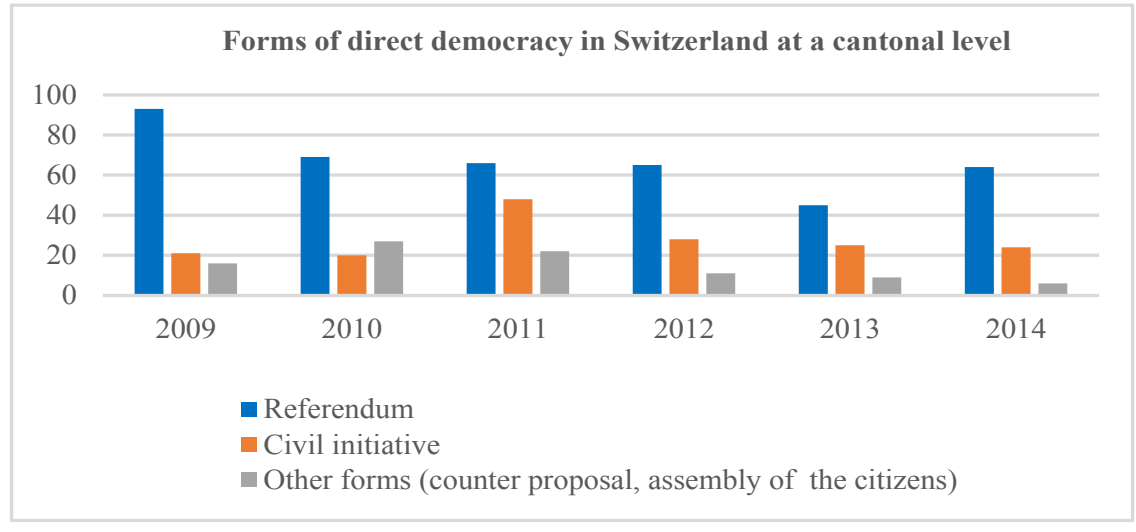

Fig. 2. Forms of direct democracy in Switzerland at a cantonal level for the period of 2009-2014

The graphs, presented in Figure 1 and Figure 2, show that the most applied form of direct democracy at the local level is the referendum in both Bulgaria and Switzerland. In second place in a view of frequency of implementation is the citizens' initiative, and to a much lesser extent the General Assembly of the Population for Bulgaria and the assembly of citizens, counter-proposal and other forms for Switzerland are used. It is noteworthy that for the period under review in Bulgaria the holding of local referendums is constant, while the local citizens' initiative and the General Assembly of the Population have been used permanently for the last three years (2012-2014). In Switzerland, all three forms of direct democracy with different degrees of implementation are traditionally applied. It should also be noted that, unlike Switzerland, which is considered a classic example of direct democracy, the intensity of the application of forms of direct government in local self-government in Bulgaria increased during the period under review. While in Switzerland, although a relative level of sustained realization is maintained, this intensity is declining. 


\section{Conclusions}

The institutions at the local level have the capacity, interest and qualifications to regulate the provision of public services, to conduct public policies, as well as to take decisions in accordance with local conditions and in line with local interests. The forces of globalization do not undermine these classic arguments for the realization of local governance. The forms of civic participation are essential for its implementation, as they improve the flow of information, accountability, transparency and give a voice to those, most directly affected by public policy [21], expressing their "active civil position" [22].

Taking into account the survey of the public registers of the proposals for holding local referendums, which are created and maintained by the chairmen of the municipal councils, it could be concluded that they reflect only the issues that will be put to the vote in the local referendum and the date of its conduction. However, no other information is available, such as the outcome of the voting in the respective local referendum and what measures have been taken to implement the decision, adopted in the local referendum in a case of a positive vote. Therefore, it is necessary to introduce mandatory details of these public registers, which reflect the entire "path" of the local referendum from its initiation to the final result - an initiating subject, the adoption or rejection of the proposal, the subject to the local referendum, as well as the adopted legal acts for its implementation. In this regard, it would be rational to be created public registers at the municipal level for the other two forms of direct democracy - the local citizens' initiative and the General Assembly, as well as to maintain a Unified National Public Register of Forms of Direct Democracy in local selfgovernment. Consideration should also be given to removing the quorum requirement for a local referendum so as not to impede its successful implementation.

\section{References}

1. Schraff, D., Schimmelfennig, F. (2020). Does differentiated integration strengthen the democratic legitimacy of the EU?: evidence from the 2015 Danish opt-out referendum. Badia Fiesolana: European University Institute.

2. Hug, S. (2003). Voices of Europe: citizens, referendums, and European integration. Lanham: Rowman \& Littlefield.

3. Drumeva, E. (2008). Konstitutsionno parvo. Sofiya: Siela.

4. Paksoy, H. M., Özçalici, M., Özbezek, B. D. (2020). Prediction of The Referendum Results According To People's Attitude Towards The Local Government. OPUS Uluslararası Toplum Araştırmaları Dergisi, 15(22), 1293.

5. Gherghina, S., Silagadze, N. (2020, October 31). Populists and Referendums in Europe: Dispelling the Myth. The Political Quarterly. Wiley Online Library. Retrieved from : https://onlinelibrary.wiley.com/journal/1467923x

6. Aleksandrova, V. (2019). Byudzheten control. Sofiya: Propeler.

7. Durana, P., Valaskova, K., Chlebikova, D., Krastev, V., Atanasova, I. (2020). Heads and Tails of Earnings Management: Quantitative Analysis in Emerging Countries. Risks, 8(2), 57.

8. Krastev, V., Koyundzhiyska-Davidkova, B., Atanasova, I. (2020). The impact of the corruption on the sustainable development of the businesses in South-West Bulgaria. In SHS Web of Conferences, 74, Art. No. 06015.

9. Diskin, A., Eschet-Schwarz, A., Felsenthal, D.S. (2007). Homogeneity, heterogeneity and direct democracy: the case of Swiss referenda. Canadian Journal of Political Science, 40, 334. 
10. Papadopoulos, Y. (2002). Connecting Minorities to the Swiss Federal System: A Frozen Conception of Representation and the Problem of "Requisite Variety". The Journal of Federalism, 32(3), 47.

11. Belov, M. (2009). Pryaka demokratsiya. Sofiya: Sibi.

12. Tsachevski, V. (2014). Shveitsariya: Demokratsiya na badeshteto. Sofiya: Iztok-Zapad.

13. Quinlan, S., Stephard, M. \& Paterson, L. (2015). Online discussion and the 2014 scottish independence referendum: flaming keyboards or forums for deliberation?. Electoral Studies, 38, 192.

14. Aubert, J.-F. (2001). Le referendum en Europe: bilan et perspectives. Paris: L'Harmattan.

15. Borstein, N., Lanz, B. (2008). Voting on the environment: price or ideology? Evidence from Swiss referendums. Ecological Economics, 67, 431.

16. Closa, C. (2007). Why convene referendums? Explaining choices in EU constitutional politics. Journal of European Public Policy, 14(8), Art. No. 1313.

17. Le Duc, L. (2005). Saving the proud or voting for Europe? Expectations for referendums on the constitution and the Euro. Journal of Elections. Public Opinion and Parties, 15(2), 170.

18. Jerzak, Connor T. (2014). The EU' democratic deficit and repeated referendums in Ireland. International Journal of Politics Culture and Society, 27, 367-388.

19. Baum, M. A., Freire, A. (2001). Political parties, cleavage structures and referendum voting: electoral behavior in the Portuguese regionalization referendum of 1998. South European Society and Politics, 6(1), 1-26.

20. Leininger, A., Heyne, L. (2017). How representative are referendums? Evidence from 20 years of Swiss referendums. Electoral Studies, 48, 84-97.

21. Sisk, T. D. (2001). Democracy At The Local Level. The International IDEA Handbook on Participation, Representation, Conflict Management, and Governance. Halmstad: Bulls Tryckeri.

22. Krasteva, N. (2009). Klod A. Helvetsii za nravstveno-pravnoto vazpitanie. Pedagogika, $1-2,141$. 